\title{
Culture in Critical Development Theory
}

The previous chapter described the place of culture in many strains of functionalist development thought. Although much of this thought has been hegemonic, especially throughout the twentieth century, it may be critiqued as largely Eurocentric, econocentric, linear, and relatively blind to multiple forms of inequality. These traits, although useful in statistical analysis and economic modelling, are unlikely to match well with the indigenous cultural visions of sustainable development emerging from Latin America and other regions of the world. There is a possibility that fruitful theoretical innovation could occur between indigenous development ideas and the capabilities approach, but this has not yet occurred.

This chapter examines the idea of culture from within more critical schools of development thought. Much like many current ideas of indigenous sustainable development, many of these theoretical frames have emerged from Latin America and other parts of the Global South. As such, they should provide a more amenable set of standpoints with which indigenous development ideas can interact.

\section{Critical Political Economy}

Critical theories emerged largely from the Marxist tradition in the early postwar period. Led by the structuralists (Prebisch 1950; Furtado 1964; Myrdal 1968), followed by dependency theorists (Amin 1976; Frank 1966; Cardoso 1972), and then world systems theorists (Wallerstein 
1974; Amin 1992; Frank 1981), these approaches tended to replace the functionalism of neoclassical theory with explanations of underdevelopment that were based in exploitation and unequal exchange. For theorists in the neoclassical tradition, markets-despite their occasional dysfunction-were thought to bring opportunity, foreign exchange, benefits from trade, investment, technology, and positive cultural influences to less developed countries. Critical theorists, however, argued that markets tend to bring subordination, exploitation, and homogenization to these countries.

\section{The Structuralist School}

Structuralist thought emerged largely in post-WWII Latin America and emphasized the importance of expanding the industrial sector for achieving economic growth. In this, structuralist thinking reflected that of the modernization theorists. Where the structuralists differed, however, was in their assistance that more was required in this process than the simple access to markets, foreign direct investment, knowledge, advanced technologies, and cultural change.

Furtado (1964) argued that structural limitations prevented successful market-based industrialization in the developing world. First, he believed that small domestic markets in many countries were not large enough to sustain the process of industrialization. Domestic industry of small economies, however, was also too weak to compete in global markets with companies from highly industrialized economies. Attempts at free-market-based industrial development, then, would leave domestic business mired in a structural trap that assures domination by stronger, more established, companies from larger economies.

Prebisch (1950) argued that difficulties in industrialization were exacerbated by a legacy of primary commodity production in former colonies. Colonial economies, he claimed, were structured to promote the export of raw materials, while advanced economies were proficient in industrial production. Because of the power of labour unions in industrial countries, and the ongoing technological development of substitutes for primary commodities, Prebisch argued that the value of primary exports compared to industrial imports was constantly decreasing-primary commodity producers in less developed countries faced declining terms of trade. Myrdal (1968) similarly argued that highly industrialized countries could capture asymmetrical benefits from trade because their economies were more 
internally integrated via forward and backward linkages. Realizing this, structuralists claimed that there existed a tendency for the highly industrialized economies of the core or centre to absorb the surplus value produced in the primary-commodity-producing periphery. This became known as the centre-periphery model (Kay 1989, pp. 29-31).

Inspired by the centre-periphery model, Prebisch (1950), Myrdal (1968), and other structuralists concluded that industrialization in the periphery was necessary in order to combat this problem. However, since they believed industrialization to be impossible in free markets, structuralists advocated for strong management of the process by the state. First, they argued in favour of import substitution industrialization (ISI) which required trade barriers to be erected which would protect government-supported businesses from international competition. When this programme was found wanting-particularly due to difficulties in higher levels of industrialization-the strategy was changed in favour of export promotion (Martinussen 1997).

Structuralist theory was generally economistic, apolitical, and acultural. An exception to this was the work of Myrdal (1968). Like the modernization theorists, Myrdal cited different cultural traits and institutional forms that existed in poorer economies and were not perceived to be conducive to development. Attitudinal problems cited by Myrdal included lack of work ethic, lack of punctuality, lack of orderliness, irrationality, superstition, inadaptability, submissiveness to authority, and fatalism. Among the most problematic institutional structures was the "soft state" which, Myrdal argued, was unable to uphold the rule of law and could easily be exploited by powerful individuals and groups. Myrdal's work spurred a move away from pristine economism in structural analysis and towards a more complex consideration of internal cultural and political conditions.

\section{Dependency Theory}

Perhaps inspired by Myrdal's interdisciplinary analysis, dependency theorists continued the critical tradition and pushed structuralism to encompass more non-economic factors. This expansion of purview was achieved initially by incorporating theories of internal colonialism and marginality into structuralist economism. The internal colonialism thesis took special note of the racial and cultural character of structurization, noting that subordinate status often corresponded to membership in a particular ethnic group. This seemed to be especially true in Latin American countries 
with large indigenous populations, such as Ecuador or Guatemala. The argument here was that, contrary to what Myrdal or the modernization theorists might say, the underdevelopment of particular ethnic groups is not due to cultural pathologies. Instead, this condition is actually a classbased domination that is simply more visible in particular populations because those groups have historically been subject to abnormal levels of exploitation. This exploitation has come because of internal unequal exchange relations with national elites, usually of European or mixed lineage, as well as from unequal exchange in the international market system (Kay 1989, pp. 59-87; González-Casanova 1965, p. 33; Johnson 1972). The marginalization thesis similarly posited that modernization policies, whether free market or ISI, tended to marginalize particular populations within a country-excluding them from the benefits of development and exploiting them for the benefit of others (Kay 1989, pp. 88-125; Quijano 1977; Germani 1972).

Andre Gunter Frank (1966) was the first dependency theorist to write in English and therefore presented the view from the South to Western development theorists for the first time. He challenged the modernization view that the development of underdeveloped countries "must and will be generated or stimulated by diffusing capital, institutions, values etc., to them from the international and national capitalist metropoles" (p. 18). Frank augmented centre-periphery theory by instead framing relations in terms of satellite and metropole. Metropoles include the advanced industrial centres of Europe and North America, which establish major trading and industrial centres in less developed countries. Through unequal relationships of exchange, the latter are perpetually subordinated to the former. Just as was the case in the centre-periphery model, the consequence of this relationship is that "metropoles tend to develop and the satellites to underdevelop" (p. 22). Frank incorporates internal factors into his analysis by insisting that each of these satellites, in turn, acts as a regional metropole. As he explains using the case of Latin America,

The metropolis-satellite relations are not limited to the imperial or international level but penetrate and structure the very economic, political, and social life of the Latin American colonies and countries. Just as the colonial and national capital and its export sector become a satellite of the Iberian (and later of other) metropoles of the world economic system, this satellite immediately becomes a colonial and then a national metropolis with respect to the productive sectors and population of the interior. Furthermore, the 
provincial capitals, which are themselves satellites of the metropolis ... are in turn provincial centres around which their own local satellites orbit ... $[E]$ ach of the satellites ... serves as an instrument to suck capital or economic surplus out of its own satellites. (p. 19)

This thinking leads Frank, along with other dependency theorists, to some stark conclusions. First, he asserts that "underdevelopment is not due to the survival of archaic institutions and the existence of capital shortage in regions that have remained isolate from world history" (p. 22). To the contrary, he argues, "underdevelopment was and still is generated by the very same historical process which also generated economic development: the development of capitalism itself" (ibid.). Through historical analysis, Frank made the case that "the regions which are the most underdeveloped and feudal-seeming today are the ones which had the closest ties to the metropolis in the past" (p. 26). Conversely, "the satellites experience their greatest economic development ... if and when their ties to the metropolis are the weakest" (p. 23). This, and similar analyses, led Frank and other of the more radical dependency theorists (Dos Santos 1971; Amin 1976; Quijano 1977; Marini 1972; García 1972) to conclude that development could only occur with a delinking of the satellite from the metropole. More moderate dependency theorists such as Cardoso (1972), Sunkel (1969), and Furtado (1971) did not disagree with this basic framework, but nuanced it with a focus on internal conditions and insisted that development could occur while maintaining such linksalthough this development will be characterized by a continuing inequality between the various satellites and metropoles.

Perhaps best thought of as an updated augmentation of dependency theory, world systems theory emerged as an increasingly dominant form of critical political economy by the end of the twentieth century. This theory is commonly associated with the work of Wallerstein (1974), and although it did not evolve explicitly out of dependency theory, key theorists such as Amin (1992) and Frank (1981) have adopted its mantle in their later work. Wallerstein (1974) argued that all economies since the sixteenth century must be analysed in relation to their position in a totalizing capitalist world system-to which there is no outside. To the structuralist dichotomy of centre-periphery, he added a semi-periphery, in describing the three relative positions in this system. The latter is useful to the function of the system because it divided the exploited - thus preventing largescale revolt. Various political and social forms that are often interpreted as 
being non-capitalist, are, he argued, expressions that represent the different positions that each occupies within the world capitalist system. Even the socialist states of the Soviet Union, he claimed, were institutional reactions designed to make the best of these countries' relative positions.

Cardoso (1972) insists that colonial and neocolonial links had been forged with peoples who "were culturally independent and structurally did not have links with the Western world" (p. 172). For most dependency theorists and world-systems theorists, it is these links, and not cultural factors, that are the cause of underdevelopment. Indeed, this is the core claim in their critique of the cultural explanation inherent in modernization theory. Gereffi (1994/2000), for example, follows Frank and Cardoso in downplaying cultural explanations, insisting that "the impact of cultural variables is most important in outlining an acceptable range of solutions to development problems, rather than in determining specific economic outcomes" (p. 233). Wallerstein (1979/2000) characterizes culture as epiphenomenal-explaining that "ethnic groups, or status groups, or ethno-nations are phenomena of world economies" (p. 201). As a result of the materialist bent that dependency and world-systems theories inherited from Marxism then, culture is often either discounted as a factor and subsequently ignored altogether or characterized as epiphenomenal-to be read-off of economic structures (Kapoor 2002).

There is, however, a substantial tradition of communication research that has drawn from dependency and world-systems perspectives. This literature is neo-Marxist in the critical political economy tradition and focuses on issues such as media imperialism (often generalized as cultural imperialism) and cultural homogenization (Tomlinson 1991). Schiller (1979), for example, argues that the massive media conglomerates of the industrialized countries provide the infrastructure that disseminates a global culture of capitalism. This media network encourages through its programming, a capitalist lifestyle of high consumption, and glorifies the trappings of capitalist modernity. In true Marxian form, Schiller argues that these media serve to encourage a commodity fetishism which serves the interest of capitalist production and blinds its victims to the true nature of their oppression. International media, he claims, act as "inseparable elements in a worldwide system of resource allocation generally regarded as capitalistic" (p. 30). These media, he continues, "create and reinforce their audiences' attachment to the way things are in the world system overall" (ibid.). This involves the creation of audiences "whose loyalties are tied to brand named products and whose understanding of social 
reality is mediated through a scale of commodity satisfaction" (p. 123). The end result is the formation of colonial subjects who venerate "the capitalist road to development" (p. 31). "The media," he continues,

now many times more powerful and penetrative than in an earlier time, are the means that entice and instruct their audiences along this path, while at the same time concealing the deeper reality and the long term consequences that the course produces. (Ibid.)

Dorfman and Metellart (1975) claim that this represents a severe form of dependency - one in which former colonies become "exporters of raw materials and importers of superstructural and cultural goods" (p. 97). Dorfman and Mettelart offer the standard dependency critique by holding that, "to service our 'monoproduct' economies and provide urban paraphernalia, we send copper, and they send the machines to extract copper" (ibid.). But the industrialized economies also send Coca-Cola-which Dorfman and Mettelart consider a cultural good. This makes dependency all the more insidious since, as they argue, "behind Coca-Cola stands a whole superstructure of expectations and models of behaviour, and with it, a particular kind of present and future society and an interpretation of the past" (ibid.). Consequently, cultural imports such as Coca-Cola and Disney cartoons are ingested by audiences in the developing world "as instruction in the way they are supposed to live and relate to the foreign power centre" (p. 98).

Salinas and Paldán (1979) reinforce the Marxist argument that cultural imperialism represents the imposition of a hegemonic ideology that promotes the continued domination of those in the peripheral economies by those in the capitalist core. They argue that the cultural institutions such as education and media systems of dependent countries are modelled to serve "the requirements of dependent industrialization" (p. 92). Since this dependent industrialization requires obedient consumers and masses of poor to ensure low labour costs, cultural imperialism can amplify suffering in the Third World by offering a modern lifestyle and denying it at the same time. As some more affluent citizens of less developed countries may be able to live the life offered by the media, "others are submitted to levels of existence that prevent them from exercising minimal cultural rights" (p. 91). They experience "a poverty of culture" (ibid.). Furthermore, argue Salinas and Paládan, the imported culture tends to dominate the indigenous to the point that the latter is pushed to extinction-resulting 
in cultural homogenization. Hamelink (1983) concurs with this homogenization thesis, offering that,

In the second half of the twentieth century, a destructive process ... threatens the diversity of cultural systems. Never before has the synchronization with one particular cultural pattern been of such global dimensions and so comprehensive. (p. 4)

As Salinas and Paldán (1979) have implied, many in the Third World have seen their culturally ascribed system of meaning eliminated by the power of international capital, only to be replaced by one that they cannot afford to participate in. So, it follows, they work in the factories and plantations that are owned by transnational industrial capital, with the hopes that they will one day earn enough to participate in the new culture from which they are excluded. All the while, the dependency relationship is maintained - the businesses of the centre accrue increasing profits brought by unequal relations of material exchange mixed with asymmetrical cultural power. Breaking this material structural relationship of exploitation is, in the end, largely thought to be a material practice. One who is hopeful for systemic change must wait in orthodox Marxism for the material relations of production to become unstable due to internal contradictions in the economic base. Culture, in the rigidly delineated Marxian tradition, often seems to be depicted as an epiphenomenon, a fetish, and an ideology. This may be an artefact of strict delineation, however. Inspired by adventurous Marxian cultural thinkers such as Gramsci (1957/1971), Althusser (1971), and Williams (1977), for example, critical political economy approaches and cultural approaches have come to share an ambiguous and porous border.

\section{Cultural Approaches}

\section{Postcolonialism}

Although much thinking in the critical political economy perspective accords most of the responsibility for the propulsion of history to the economic base, Marxism did produce a significant strand that attributed a large amount of power to the ideological. As we discussed in the first chapter, Antonio Gramsci was perhaps the first Marxian thinker to suggest that social change may be incited via interventions in the ideological 
realm-that cultural change could force systemic change. This insight was taken up with revolutionary fervour, first in anti-colonial struggle by Senghor (1956), Césaire (1953/1972), and Fanon (1952/1967), and then in opposition to forms of neocolonialism by Freire (1970), Said (1979), Bhabha (1986), and Spivak (1988), amongst others. The key tenet of this thought is as follows: "that representations and modes of perception are used as fundamental weapons of colonial power to keep colonized peoples subservient to colonial rule" (McLeod 2000, p. 17).

Perhaps the most thorough treatment of culture and its relation to human subjectivities in early postcolonialism appears in Frantz Fanon's (1952/1967) Black Skin, White Masks. Fanon was primarily concerned with racism, which he perceived to be "a cultural element" (1967, p. 32). Racism, however, was the product of an entire colonial worldview which was produced by the colonizer via language, and then internalized and reproduced by the colonized. Within the colonies, Fanon (1952/1967) argues,

there is a constellation of postulates, a series of propositions that slowly and subtly, with the help of books, newspapers, schools and their texts, advertisements, films, radio, penetrate and individual—constituting the worldview of the group to which one belongs ... that world-view is white because no black voice exists. (p. 152)

As the quotation suggests, Fanon utilizes a model in which human consciousness, propensities, thoughts, and tastes are produced from without through the communicative innovation of language. Fanon (1952/1967) argues that the production of the human mind, with its beliefs, wants, and desires, "is not dependent on cerebral heredity; it is the result of ... the unreflected imposition of culture" (p. 191). Once subsumed by the worldview of the European, the colonial subject holds "the same fantasies as a European" (ibid.). This is not due to some stable and universal set of attitudes and wants endowed to every human; rather, it is because the colonial subject "partakes in the same collective unconscious as the European" (ibid.).

A psychoanalyst by training, Fanon broke with the tradition of Jung and Freud who tended to accord internal causes to psychological problems. Drawing more on Lacan, Fanon insisted that any neurosis experienced by the colonized was cultural in origin. For him, there was no internal tension or conflict that was not a social one as well. As the 
colonized subject internalized the values of liberal twentieth-century France, he internalized tension. Lifestyle promises and liberal ideals of equality were delivered with the message of racism. At the same time, colonized peoples became the receivers of culture-being robbed of the confidence and power to create and change it. Thus, the colonized culture "becomes closed, fixed in the colonial status, caught in the yoke of oppression" $(1967$, p. 34). This runs contrary to the natural character of culture, "to be open, permeated by spontaneous, generous, fertile lines of force" (ibid.). Fanon claimed that the eventual result of this tension and rigidity would be a violent break that would result in both the decolonization of colonized territories and of colonized minds. Fanon advocated that new nations be formed which would be based on true equality and cultural creativity - in which colonial racist binaries would be dismantled.

Similarly, Paulo Freire (1970) holds that human consciousness and unconsciousness are produced communicatively through language. In this way, the economic domination of particular groups is conjoined with a cultural domination. As he argues,

The oppressor consciousness tends to transform everything surrounding it into an object of its domination. The Earth, property, production, the creations of people, people themselves - everything is reduced to the status of objects at its disposal... [A]t a certain point in their existential experience the oppressed feel an irresistible attraction towards the oppressors and their way of life. Sharing this way of life becomes an overpowering aspiration. In their alienation, the oppressed want at any cost to resemble the oppressors, to imitate them, to follow them. (pp. 58-62)

This infusion of the tastes, beliefs, and ideas of the oppressor is delivered through multiple media, but Freire is most concerned with formal education. The "pedagogy of the oppressed," which creates colonial subjects, must, he argues, be replaced by a "pedagogy of liberation," which involves the creation of a critical space in which the "reality" of this subjugation is "unveiled" and both student and teacher embark on the recreation of knowledge (p. 69). In this way, the oppressed may chart their own emancipatory course from the domination of capitalist-liberal ideology and racism, towards the regaining of their "humanity" (p. 44). Freire, Like Fanon, posits this humanity as a natural state of man, based in cultural and material equality. The ideology of the oppressor is painted as a false consciousness, a fetish, a dominating ideology, as would be expected 
with critical Marxist approaches. The difference here-the nuance that makes this a cultural approach-is that cultural relations based in racism and other forms of colonial domination are thought to be injurious in their own right, irrespective of material dependency. Furthermore, Both Freire and Fanon insist that colonialism and neocolonialism can be overturned by interventions in the cultural, even suggesting that such interventions are prerequisites to material emancipation.

The next stage in postcolonial thought was, in many ways, prefigured by the cultural analysis of Freire and Fanon. This was a turn to a poststructuralism which turned on the insistence that all meaningful human experience was made intelligible through language, and consequently, that tastes, thoughts, "material" needs, and ideas are collectively determined through culture. The autonomous self-the economic agent-was for the post-structuralists a decentred subject; a hollow space that is continuously colonized and given substance by multiple discourses that define what liberal philosophers had previously called "the individual."

The form of post-structuralism that was imported into postcolonialism was based around the work of Michel Foucault (1980). ${ }^{1}$ Very similar to the Lacanian vision used by Fanon, the cultural world that is produced by language is thought by Foucault to structure the cognitive world of the individual, giving shape to his or her tastes, logics, and desires. Discourse, for Foucault, makes the world apprehendable by imbuing it with meaning. By making the world understandable in particular ways, discourse motivates the actions and choices of individuals. Discourse itself is simultaneously discursively constructed, however, as Hall (2002, p. 60) explains:

Discourse is about the production of knowledge through language. But it is itself produced by a practice: "discursive practice"-the practice of producing meaning. Since all social practices entail meaning, all practices have a discursive aspect. So discourse enters into and influences all social practices. (60)

These discourses, for both Hall and Foucault, are co-produced by many individuals - although the extent of an individual contribution to this production is tightly correlated with power. Discourses, however, are not

\footnotetext{
${ }^{1}$ It should be noted that both Foucault and Derrida were heavily influenced by their experiences during the Algerian War of Independence, which would have inevitably brought them into close contact with much early postcolonial thought - especially that of Fanon-as they formulated their ideas regarding the human experience (Alhassan 2007).
} 
thought to be closed systems (they are always adjusting to influences from without) and are relatively cohesive (never random), although they need not be completely internally consistent or conflict-free. The poststructuralist preoccupation with discourse differs from the use of culture by Fanon and Freire in that the latter maintains an underlying notion that colonial discourses serve to obscure a particular "truth" regarding subjugation. This is consistent with the Marxian concept of ideology. Poststructuralists argue, on the other hand, that, since the world can be given multiple meanings via discourse, a "fact" can be construed in different ways. The task of the social scientist, grassroots revolutionary, or the policy analyst, then, moves away from "deciding which social discourses are true or scientific, and which false or ideological" (Hall 2002, p. 62). What things come to count as true, for Foucault, is the outcome of a struggle for meaning that is weighted by power:

We should admit that power produces knowledge.... That power and knowledge directly imply one another; that there is no power relation without the correlative constitution of a field of knowledge, nor any knowledge that does not presuppose and constitute ... power relations." (1980, p. 27)

Perhaps the most prominent post-structural work regarding colonial thought is Edward Said's (1979) Orientalism. Said draws on Gramsci, Fanon, Foucault, and Lacan in arguing that the lived experience of Western subjects is produced partially by a discourse of Orientalism-a textually produced depiction of the world in which the peoples of the Global South are depicted as degenerate, traditional, and irrational. Said is careful to make clear that this discourse is not to be "mistaken as merely decorative or 'superstructural'," as is the case with the Marxian-Gramscian ideas of hegemony and ideology (p. 25); rather, that the authority it exudes "establishes canons of taste and value" (p. 19). The discourses of Orientalism help to produce the Western individual, complete with his or her preferences and assumptions about the world. Orientalism is tied to political interest for certain, but "it was the culture that created that interest," not the interest that created the culture (p. 12). Said includes all forms of Western writing about the orient in this discourse, but also the messages included in the seemingly objective Western social sciences, such as economics.

Arguments related to postcolonialism are diverse and complex, and they do not suit the current purpose to delve deeply into this literature. 
The post-structural insights discussed earlier, however, are important for our interest in culture, since they claim the individual to be a collective construct. Debates regarding the possibility of the subaltern to resist the totality of such discourses pertain to our interest in the concept of development as well. This is the case, as it could be argued that since discourse can provoke feelings of diminishment while validating forms of material subjugation, moves to counter such discourses might be thought to represent development. Resistance is generally thought to imply development in the broadest sense in postcolonial works, and arguments run the gamut between those insisting that resistance is possible (Bhabha 1986; Appadurai 2000; Banerjee 2002) or even ubiquitous, and those who suggest that it may be exceedingly difficult to break from such omnipresent discourses, if not impossible (Spivak 1988; Gates 1992).

\section{Post-Development}

If postcolonialism represents a critique of the cultural power exerted over the peoples of Global South through the discursive construction of weighted binaries such as West/rest and primitive/modern, postdevelopment may be thought of as a refined strand of that critique. The linguistically constructed colonial binary at stake in post-development theory is that of developed/underdeveloped. Although much attention is given to Arturo Escobar's (1994) doctoral dissertation Encountering Development as a founding text in the field, the discursive force of postdevelopment thought was largely centred on edited readers by Sachs (1991) and by Rahnema and Bawtree (1997) as well.

In these works, the idea of development is attacked as a colonial discourse. Rahnema and Bawtree (1997) reprint a classic work by Sahlins in making the fundamental post-development argument that, in Sahlins' words,

The world's most primitive people have few possessions, but they are not poor. Poverty is not a certain small amount of goods, not is it just a relation between means and ends; above all, it is a relation between people. Poverty is a social status. (p. 19)

Using this logic and basing his argument on historical interpretation, Sahlins argued that the assumptions of the nature of man and poverty that pervade Western thought-Marxist and especially liberal economic-make 
little sense. When discussing an apparent indifference to poverty amongst hunters and gatherers, Sahlins holds,

[I]t seems wrong to say that wants are 'restricted', desires 'restrained', or even that the notion of wealth is 'limited'. Such phrasings imply in advance an Economic Man and a struggle of the hunger against ones own worst nature, which is finally then substituted by a cultural vow of poverty.... [Rather], economic man is a bourgeois construction.... It is not that hunters and gatherers have curbed their materialistic 'impulses': they simply never made an institution of them. (p. 10)

Post-development theorists argue that development "experts" entered this milieu, propelled by and propelling the Eurocentric discourse of development. These experts, hailing from the West and privileged castes of the former colonies, began by using discourse to imply "abnormalities" such as "underdeveloped," "malnourished," "poor," and illiterate" (Escobar 1999b, p. 322). To be "developed" came to imply "being like the West." To be "underdeveloped" was to live in any other way. "Traditional" knowledges and ways of life were in this way devalued. Development discourse was internalized by many of the newly defined "poor" under the weight of the authoritative discursive power of Westerntrained experts. These ideas of non-Western inferiority were institutionalized through the "professionalization" and "technification" of development. University departments and academic disciplines were established throughout the developed world, where experts sought to,

Establish the nature of Third World countries, to classify their problems and formulate policies, to pass judgement on them and visualize their future- to produce, in short, a regime of truth and norms about development...[;] a field of control of knowledge, through which truth (and, so, power) was produced. (Ibid., pp. 322-323)

With many similarities to Polanyi's (1944) work, Escobar (1999a) argues that the discipline of development economics sits at the core of this discursive machine which,

must be analyzed within the context of the establishment of economics as a "positive," "objective," science, thanks in part to the development—during the past 200 years — of a culture in which a specific economic rationality ... became dominant. This process, which one can perhaps call the 
"economization of life," was intimately linked to the development of capitalism; it entailed as necessary prerequisites the establishment of the normative discourse of classical political economy. (Ibid., p. 323)

Rahnema and Bawtree (1997) describe development discourse as a cultural viral infection. This virus, he argues, "penetrates into peoples' minds," propelled by "the school system, the production of addictive needs, and the dis-valuation of indigenous know-how" (p. 119). In human history, he argues, “'economic' man represents a novelty."

He developed, indeed, in the womb of early capitalism, and his identity card could have been stamped with the words 'white', 'European' and 'male'. Yet he took pride in proclaiming his 'freedom' from belonging to any particular tribe or community, roots or culture, village or oasis. He was an a-cultured, uniform and substitutable person. He perceived himself as an 'individual' rather than a 'member of the community'. (p. 116)

Rahnema argues that the cultural beast, economic man, invaded colonial and postcolonial societies, destroying "the basic institutions of local populations," and that he did this "under the banner of development" (p. 118). It is through development discourse that,

homo economicus transforms all his prey into 'economic men', like himself, substituting their motives of subsistence and their sense of belonging to the community with those of gain and of full 'individual freedom'. (p. 119)

Those who critique post-development thought often insist that it tends to romanticize poverty and tradition, or that it is hopelessly relativistic. Although it is not true that post-development theorists, or the poststructural theorists they based their work on (Foucault, Derrida), acted without ethics, it does seem that their theoretical construct left little space within which to formulate one. The strength of the post-development critique of cultural and material imperialism, it seems, may have been bought, at least initially, at the expense of any sense of progress. Post-structural assertions that humans engage the world through a largely self-referential, ever-evolving, system of symbols leave themselves open to a critique of cultural reductionism that denies a real material world. The assertion that human values are based in such symbolic systems, similarly, has led to critiques of relativism. Consequently, caricatures of post-structuralism and 
post-development conjure a theory in which human reality can be changed by pure imagination, even the most atrocious abuses and inequalities can be justified through appeals to culture, and one in which there is simply no such thing as development (Rao and Walton 2004; Pieterse 2000).

\section{Cultural Political Economy}

If it were ever true that post-development theorists failed to transcend mere relativistic critique and to forward a substantive ethic with which to conceive social progress, this problem did not last long. Conversely, if political economy approaches to development tended to be irredeemably materially reductionist during the twentieth century, recognition of the autonomy and co-determining power of culture became prevalent into the twenty-first century. In this section, I propose that, as a result of these movements, a meaningful theoretical conversation has taken place between cultural and critical political economy approaches in development studies. With contributions from both the culturalists and the political economists, I suggest that this dialogue represents the emergence of a cultural political economy of development.

This is not to deny, for example, that there is a valid and relevant postdevelopment school that contains a subtle, non-relativistic critique that is not mired in cultural reductionism. Nor is it meant to suggest that the political economy of development has not incorporated cultural insights meaningfully into its analysis. The category of cultural political economy is evoked here to recognize that much of the more sophisticated political economy work and more recent permutations of post-development have become strikingly similar-that the schools have converged.

Pieterse (2000) perhaps began the move from the culturalist side by insisting that the focus of the post-development critique is really on modernization theory and the system of development that emerged in the post-WWII period, instead of against the idea of development itself. He also claims that most post-development theorists do not succumb to romanticism and relativism, but partake in a "reflexive development, in which a critique of science is viewed as part of development politics" (2000, p. 343). Consistent with Pieterse's claims, many post-development theorists have advocated the support of grass-roots "new" social movements based on gender and other forms of identity as well as class, and participatory forms of development interventions, policy formulation, and research, instead of technocratic economistic "top-down" development 
plans instituted by governments and transnational institutions (Nelson and Wright 1995; Alvarez et al. 1998).

Pieterse's assertions may well be true, but they are based in observations of the praxis of post-development thinkers, not on any theoretical advancement that transcends the relativist trap. Through the advancement of what Escobar (2007) calls the "Latin American modernity/coloniality (MC) research program" (p. 179), however, it has increasingly been argued that a modern-style ethic of equality is not necessarily discordant with a cultural approach. Based largely on the writings of Dussel (1980), this school insists first that it is arrogant to assume that modernity was solely a European construction and therefore has little to do with pristine cultures that sit somewhere outside its borders. Second, while Dussel claims his theory to be posmodern, and later transmodern (2012), he insists that this does not imply an idealist world divorced from materiality-rather a cultural world that operates in relation to a material world which, nonetheless, must be symbolically interpreted to have meaning to human actors.

This theoretical innovation buys post-development theorists much in the way of theoretical buttressing for their already existent praxis. "Transmodernity" implies first that there is no outside of modernity in current global semiotic structures, but there are margins from which cultural innovation can, and does, emerge. This concept is accomplished by "locating the origins of modernity with the Conquest of America and the control of the Atlantic after 1492, rather than the most commonly accepted landmarks such as the Enlightenment or the end of the eighteenth century" (Escobar 2007, p. 184). This allows a "world perspective in the explanation of modernity, in lieu of a view of modernity as an intraEuropean phenomenon" (ibid.). This process did not occur without asymmetries of power, however, as "the domination of others outside the European core" and the "subalternization of the knowledge and cultures of these other groups" typified the process in which modernity was constructed (ibid.). As a result of this line of thought, one can continue to prescribe to a post-structuralism, or post-developmentism, while maintaining a commitment to modern virtues such as equality, human rights, and democracy widely construed.

Material and economic dimensions are not diminished in this perspective. The project, Escobar (2007) argues, has been undertaken with "a persistent attention to colonialism and the making of the capitalist world as constitutive of modernity" which "includes a determination not to 
overlook the economy and its concomitant forms of exploitation" (p. 184). Modernity, then, was co-built globally by colonizers and colonized, but with a Eurocentrism that was underwritten by military and economic power. This does not mean, however, that other forms of thought do not have interpolating power in this constellation. Development, in fact, requires an equalization of this interpolating power via

the interpellation which the majority of the population of the planet, located in the South, raises, demanding the right to live, the right to develop their own culture, economy, politics, etc. ... There is no liberation without rationality, but there is no critical rationality without accepting the interpellation of the excluded, or this would inadvertently be only the rationality of domination. (Dussel and Mendieta 1996, pp. 31 \& 36)

Nearly simultaneous to this theoretical move from relativism and idealism on the part of the post-structuralists has come a meaningful attempt by critical political economists of development to move beyond the depiction of culture as mere materially determined ideology. Central to this is the work of Jessop and Ngai-Ling Sum (2001), who embrace "the post-disciplinary 'cultural turn' for rethinking political economy" (p. 92). This involves supplementing Marxism with a "discursive account of power" which,

involves the claim that the interests at stake in relations of power are significantly shaped by the discursive constitution of identities, modes of calculation, strategies and tactics and not just by the so-called 'objective' position of specific agents in a given conjuncture (as if they existed outside of discourse); and also [an admission that] that the primary institutional mechanisms in and through which power is exercised, whether directly or indirectly, themselves involve a variable mix of discursive and material resources. Another key feature [concerns] ... emphasis on the social construction of knowledge and truth regimes. (p. 93)

This embracing of the cultural is, however, "subject to certain modifications that re-assert the importance of the materiality of political economy" (ibid., p. 92). Central to this is an emphasis on "the materiality of social relations and the constraints involved in processes that also operate 'behind the backs' of the relevant agents," as well as on the historically contingent evolutionary nature of cultural and other institutions (ibid., p. 94). Resultantly, Jessop and Sum claim that this new political economy 
can "escape the sociological imperialism of pure social constructionism and the voluntarist vacuity of certain lines of discourse analysis, which seem to imply that one can will anything into existence in and through an appropriately articulated discourse" (ibid.).

What I would like to suggest here is that the simultaneous intellectual augmentations of the post-structuralists and the critical political economists described earlier have resulted in the inadvertent cohabitation of a new school of development thought cultural political economy. ${ }^{2}$ This school has four main features. First, although it recognizes the discursive constitution of meaning, the school emphasizes the path-dependent nature of linguistic structure-another world is possible, but any world is not possible, since all worlds are only imaginable through the use of already existent semiotic tools. Second, a material, natural world exists outside of culture, although to be made intelligible, it must be discursively interpreted. Third, cultural political economy features a commitment to an egalitarian ethic in both cultural and material terms (although it recognizes both these terms to be little more than abstractions since they are coterminous). Fourth, cultural political economy is interdisciplinary-this has meant engagement with political economy, cultural studies, anthropology, geography, linguistics, and sociology, but not as of yet with neoclassical economics.

The emergence of cultural political economy (CPE) has not simply been an academic pursuit. A cultural political economy approach to development has also been championed by indigenous groups at global, national, and local scales (Mander and Tauli-Corpuz 2006). As Blaser, Feit, and McRae (2004) have elucidated in an edited volume that contains contributions from indigenous leaders, such groups have often rejected modernizationist, neoliberal, externally devised, as well as state- or corporate-led development initiatives. Focus has been placed by indigenous peoples on the realization of life projects (as opposed to development projects) that emphasize local culturally situated values and goals, solidarity and self-governance. Life projects, according to Blaser, Feit, and McRae, do not, however, distil to a simple romanticization of imagined traditional lifestyles and outright rejection of ideas related to economic growth, development, or social progress. Although the culturally situated nature of human values and lifestyles is forefronted, indigenous groups also seek

\footnotetext{
${ }^{2}$ This term is explicitly used by Jessop and Sum and also by Best and Paterson (2007), although the latter do not apply the theory specifically to development issues.
} 
material advancement and the acquisition of productive resources-primarily of land-in a struggle for subsistence. Blaser, Feit, and McRae show that assertions related to the primacy of culture coexist in indigenous politics with appeals to universal rights. Furthermore, locally situated projects and politics in indigenous communities are linked inextricably to broader international solidarity and environmental movements.

\section{Culture and Sustainable Development}

A cultural political economy approach to development brings together theoretical understandings with praxis just as it allows the co-determined nature of material and cultural elements. One of the areas where CPE can be seen most vividly is in the area of sustainable development. Well before the Club of Rome's (Meadows et al. 1972) assertion that there are environmental limits to development defined strictly as increasing income per capita, a tension between economic development and the natural environment had been noted. Polanyi (1944) spent much time, for example, describing the environmental catastrophe that was apparent in the eighteenth-century economy.

The Brundtland et al. (1987) report formalized this dilemma, using the term "sustainable development" to describe "development that meets the needs of the present without compromising the ability of future generations to meet their own needs." The integration of a CPE approach (along with the strong voices of postcolonial and indigenous movements) requires us to question just what this "development" is that is to be "sustained." Nurse (2006) produced an insightful contribution by insisting that culture be made a "pillar" of sustainable development. By this, he meant that we must understand how culture frames both the production and consumption side of development. On the consumption side, we must not assume to know what the end point of human flourishing is. This opens the door to a grounded redefinition of "the good life" from indigenous and other perspectives. On the production side, this suggests that that there are multiple social practices, actions, and understandings that might produce this development.

As Blaser et al. (2004) and others have documented, indigenous peoples have taken a leading role formulating this new form of sustainable development. This often involves the evocation of indigenous "life projects" that break substantively and ontologically from the mainstream concept of "development." A less radical break from mainstream development 
is present in the use and valuing of traditional ecological knowledge (TEK) by mainstream developmental and ecological organizations. For example, the International Panel on Climate Change attempts to integrate TEK into its analyses and policy prescriptions, and the Canadian government proposes the use of the intimate ecological knowledge of indigenous peoples in the service of environmental impact assessment. Such uses of TEK are laudable for their admission of the value of indigenous knowledge, but tend to view such knowledge as a resource to be used by non-indigenous agencies to achieve their policy or measurement goals—not as a valuable cultural and ontological contribution to the redefinition of the meaning of developmental and human-environment relations.

A CPE approach allows us to engage with grounded struggles for meanings and material resources implicated when indigenous groups assert their power to redefine the meaning of development itself. It also allows an engagement with the breaking of the human-nature binary that is implied by indigenous worldviews. The hope embodied in a CPE approach is that sociologists, political scientists, anthropologists, indigenous peoples, and economists may be able to use it as a meeting place within which they can form mutual understandings that could lead to positive change in collaboration with indigenous peoples. The necessity of sustainability mandates that this change be embedded in a flourishing ecosystem.

\section{ConClusion}

The work undertaken in the last two chapters began with a claim that there exists an uncomfortable silence between cultural and political economy approaches to development on one side, and neoclassical economic approaches on the other. After reviewing the intellectual history of development thinking from the eighteenth century onwards, it is apparent that this failure of communication is the consequence of old disciplinary commitments that have become entrenched due to both methodological expedience and ideological convenience.

For classical political economists beginning with Smith and continuing in varying degrees through to Mill, considerations of culture and ethics were common. These considerations were held separate from economic analysis in all cases, due to a methodological need to assume Smith's selfinterested, atomistic personal-gain-maximizing actor-homo economicus - as the primal unit for economic analysis. Only with the 
assumption of homo economicus would Smith's metaphor of the selfregulating market with its invisible hand make analytical sense. Questions of culture and ethics, although extremely prevalent in the works of the classical political economists, were considered separately so as not to interfere with the elegant functioning of early economic models. It should not be forgotten, however, as Polanyi (1944) has argued, that the segregation of economic and cultural/ethical realms, and the obfuscation of the latter, served the ideological interest of a powerful merchant colonial class whose power rested on the institutionalization of private property rights and market-based economies in the eighteenth century.

These interests and methodological expediencies continued and became solidified through the nineteenth and twentieth centuries. Especially significant in this regard was the marginal revolution which completed the amputation of culture from economy. This was achieved via the methodological adoption of differential calculus which allowed for the mathematization of economics and the disciplines' subsequent ascendance to become the "queen of the social sciences." All the while, it must be remembered, lingering class interests exerted their ideological pressures on the refining of economic thought.

The recognition of cultural difference that accompanied attempts to "develop" newly emergent postcolonial nations in the post-WWII period posed a particular problem for economic theory. The culturally situated actions of peoples of non-European descent did not fit the prerequisites of the economic model. Neoclassical economists responded with a proclamation that traditional culture in the former colonies was exerting a pressure on economic actors in those regions that caused them to behave irrationally. This prompted a temporary alliance with certain sociologists who were enlisted to identify particular cultural pathologies of traditional societies and to devise plans for the cultural cure. They were to then deliver fully formed homo economici to the economists so that the latter could finally actualize their technocratic development plans. Although this seemed to be a period of interdisciplinary cross-fertilization, it could be more accurately described as disciplinary specialization which saw sociologists act in the service of waiting neoclassical economists-subservient social scientists paying discursive homage to the "queen."

With the advent of new classical economics, this interdisciplinary arrangement was terminated. For the Chicago School economists of this tradition all people were considered rational; culture was therefore largely irrelevant, and so was the work of other social scientists. It was 
(non-cultural) institutional change that was needed to allow the benefits of self-interest to fruitfully accrue, not some sort of cultural engineering. Free markets were the order of the day. It was presumed that rational actors in the Global South would act efficiently within a market-centric institutional setting.

New institutional economists went further in the depreciation of culture vis-à-vis homo economicus as they came to recognize culture as the result of the self-interested action of stable (in their preferences) economic actors. Culture was one of many possible strategic constructions of maximizing automatons in the face of market failures caused by the existence of public goods and associated externalities. Nonetheless, the idea of pathdependency revived modernization theory as it was argued that the onceefficient cultural institutions could become suboptimal equilibriums as technology and other institutional factors change. New institutionalism resultantly invited the intervention of technocrats to legislate between good and bad, efficient and inefficient, culture-supporting the former, while dissuading the latter.

Critical political economists from Marx in the nineteenth century, through to Frank and Wallertstein in the twentieth century, maintained a scepticism towards liberal economics. These thinkers deftly brought attention to the ways in which free-market economies tended to exacerbate inequalities and perpetuate class-based and colonial domination. Culture, however, became separated from, and marginalized in comparison to, what was considered to be a determinant material sphere. This material reductionism was countered by postcolonial and post-development culturalism. These theorist tended to err in the other direction, however, leaving themselves open to critiques of idealism, cultural reductionism, and excessive relativism.

The seemingly incommensurable divide between culturalists and critical political economists has recently been bridged through the advent of various approaches to cultural political economy. By insisting that modernity and the associated ethic of equality were co-produced by colonizers and colonized, and that there was no outside of this cultural formationjust difference at the margins-modernity/coloniality theorists such as Dussel and Escobar escaped the relativist trap. This idea has been increasingly referred to a transmodernity. Similarly, through an insistence that a material extra-cultural world existed, yet must be interpreted symbolically, they countered critiques of idealism. Simultaneously, attempts have been made by political economists to take culture seriously by introducing a 
discursive concept of power and admitting that the cultural and material are co-determining. The familiar intellectual quagmire of relativistic idealism was avoided through an appeal to the path-dependent nature of human language, material constructions, and lived experience. Cultural political economy, it seems, represents a powerful collaborative project of the cultural and critical political economy schools as well as grassroots, especially indigenous, movements.

Communication and cooperation between these groups and neoclassical economists has been much more problematic. The methodological presumption of egoistic, atomistic human actors with stable preference sets seems to preclude any fruitful exchange between neoclassical economists and culturalists. The tendency of neoclassical economists to uncritically valorize and reify markets does not sit well with critical political economists. The most coherent attempt to contribute to cultural political economy from the neoclassical side has come through the capability approach. Perhaps due to the difficulty of this theoretical challenge, however, this approach has yielded a large portion of ambiguity. As a result, the incentive for academic neoclassical economists, as well as those in bilateral and multilateral institutions, has been to borrow from the capability approach piecemeal. This implies the use of broader indicators of development-such as the Human Development Index-for the measurement of development, or the use of participatory approaches to facilitate the implementation of projects that have largely been designed by the economists, or other technocrats, themselves. As a result, the very parts of the capabilities approach that may resonate with cultural political economists - such as the encouragement of genuine grassroots participation, the challenging of power structures, and the recognition of multiple definitions of development- tend to be culled by neoclassical economists (Bebbington et al. 2004).

This book represents an attempt to breach the communication gap between critical political economists and culturalists on the one side, and neoclassical development economists on the other. This is to be done via an integration of indigenous concepts of sustainable development into development theory. The undertaking is not meant to displace or discredit the capabilities approach, but to work towards clarifying it. Such work will entail a contribution to cultural political economy that begins with the neoclassical approach. To be consistent with a cultural political economy approach, this would imply an inductive empirically grounded exploration which privileges the local knowledge of the marginalized-in this case, Latin American indigenous peoples. 


\section{REFERENCES}

Alhassan, A. (2007). The Canonic Economy of Communication and Culture: The Centrality of the Postcolonial Margins. Canadian Journal of Communication, $32(1)$.

Althusser, L. (1971). Ideology and the State. In Lenin and Philosophy and Other Essays (Vol. 2). Paris: François Maspero.

Alvarez, S. E., Dagnino, E., \& Escobar, A. (1998). The Cultural and the Political in Latin American Social Movements. In S. E. Alvarez, E. Dagnino, \& A. Escobar (Eds.), Cultures of Politics, Politics of Culture. Colorado: Westview Press.

Amin, S. (1976). Unequal Development: An Essay on the Social Formation of Peripheral Capitalism. New York: Monthly Review Press.

Amin, S. (1992). Empire of Chaos. New York: Monthly Review Press.

Appadurai, A. (2000). Disjuncture and Difference in the Global Cultural Economy. In S. During (Ed.), The Cultural Studies Reader (2nd ed., pp. 220-230). London: Routledge.

Banerjee, I. (2002). The Locals Strike Back?: Media Globalization and Localization in the New Asian Television Landscape. Gazette: The International Journal for Communication Studies, 64(6), 517-535.

Bebbington, A., Guggenhiem, S., Olson, E., \& Woolcock, M. (2004). Exploring the Social Capital Debatess at the World Bank. Journal of Development Studies, $40(5), 33-64$.

Best, J., \& Paterson, M. (2007). Cultural Political Economy. Workshop on Cultural Political Economy. University of Ottawa, June 15-17, 2007.

Bhabha, H. K. (1986). The Other Question: Difference, Discrimination and the Discourse of Colonialism. In F. Parker, P. Hulme, \& M. Iverson (Eds.), Literature, Politics, and Theory: Papers from the Essex Conference 1976-1984. London: Methuen.

Blaser, M., Feit, H. A., \& McRae, G. (2004). In the Way of Development: Indigenous Peoples, Life Projects, and Globalization. Ottawa: IDRC/Zed.

Brundtland, G., Khalid, M., Agnelli, S., Al-Athel, S., Chidzero, B., Fadika, L., et al. (1987). Our Common Future. Brundtland Report.

Cardoso, F. H. (1972). Imperialism and Dependency in Latin America. In F. Bonilla \& R. Girling (Eds.), Structures of Dependency. Stanford, CA: Institute of Political Studies.

Césaire, A. (1953/1972). Discourse on Colonialism. New York: Monthly Review Press.

Dorfman, A., \& Metellart, A. (1975). How to Read Donald Duck: Imperialist Ideology in the Disney Comic. New York: International General Editions.

Dos Santos, T. (1971). The Structure of Dependence. In K. T. Fann \& D. C. Hodges (Eds.), Readings in U.S. Imperialism. Boston: Porter Sargent. 
Dussel, E. (1980). The Philosophy of Liberation. New York: Orbis.

Dussel, E. D. (2012). Transmodernity and Interculturality: An interpretation from the Perspective of Philosophy of Liberation. Transmodernity: Journal of Peripheral Cultural Production of the Luso-Hispanic World, 1(3).

Dussel, E. D., \& Mendieta, E. (1996). The underside of modernity: Apel, Ricoeur, Rorty, Taylor, and the philosophy of liberation. Atlantic Highlands, NJ: Humanities Press.

Escobar, A. (1994). Encountering Development: The Making and Unmaking of the Third World. Princeton: Princeton University Press.

Escobar, A. (1999a, November). The Invention of Development. Current History, 382-386.

Escobar, A. (1999b). Discourse and Power in Development: Michel Foucault and the Relevance of His Work to the Third World. In T. L. Jacobson \& J. Servaes (Eds.), Theoretical Approaches to Participatory Communication. Cresskill, NJ: Hampton Press.

Escobar, A. (2006). Places and Regions in the Age of Globality: Social Movements and Biodiversity Conservation in the Columbian Pacific. Mimeo: Department of Anthropology, University of North Carolina. Retrieved from http://www.unc. edu/ aescobar/text/eng/places_regions.doc.

Escobar, A. (2007). Worlds and Knowledges Otherwise: The Latin American Modernity/Coloniality Research Program. Cultural Studies, 21(2), 179-212.

Fanon, F. (1952/1967). Black Skin, White Masks. New York: Grove Press.

Foucault, M. (1980). Power/Knowledge: Selected Interviews and Other Writings, 1972-1977. Vintage.

Frank, A. G. (1966). The Development of Underdevelopment. Monthly Review, $18(4), 17-31$.

Frank, A. G. (1981). Crisis in the Third World. London: Heinemann.

Freire, P. (1970). Pedagogy of the Oppressed. New York: Continuum.

Furtado, C. (1964). Development and Underdevelopment: A Structural View of the Problems of Developed and Underdeveloped Countries. Berkeley: University of California Press.

Furtado, C. 1971. Dependencia Externa y Teoria Economica. El Trimestre Economico, 38, 335-349.

García, A. (1972). Atraso y Dependencia in América Latina; Hacia una teoría Latinoamericana de Desarollo. Buenos Aires: El Eteneo.

Gates, H. R., Jr. (1992). “Race," Writing, and Difference. New York: Barnes \& Noble.

Gereffi, G. (1994/2000). Rethinking Development Theory: Insights from East Asia and Latin America. In J. Timmons Roberts \& A. Hite (Eds.), From Modernization to Globalization: Perspectives on Development and Social Change. Malden, MA: Blackwell. 
Germani, G. (1972). Aspectos Teóricos de la Marginalidad. Revista Paraguaya de Sociología, 9(30), 7-35.

González-Casanova, P. (1965). Internal Colonialism and National Development, Studies in Comparative International Development. In I. L. Horowitz de Castro \& J. Gerassi (Eds.), Latin American Radicalism (pp. 118-139). London: Jonathan Cape.

Gramsci, A. (1957/1971). Selections from the Prison Notebooks. New York: International Publishers.

Hall, S. (2002). The West and the Rest: Discourse and Power. In S. Schech \& J. Haggis (Eds.), Development: A Cultural Studies Reader. Malden, MA: Blackwell.

Hamelink, C. J. (1983). Cultural Autonomy in Global Communications: Planning National Information Policy. New York: Longman.

Jessop, B., \& Sum, N. (2001). Pre-disciplinary and Post-disciplinary Perspectives. New Political Economy, 6(1), 89-101.

Johnson, D. L. (1972). On Oppressed Classes. In J. D. Cockroft, A. G. Frank, \& D. L. Johnson (Eds.), Dependence and Underdevelopment: Latin America's Political Economy. New York: Doubleday.

Kapoor, I. (2002). Capitalism, Culture, Agency: Dependency Theory versus Postcolonial Theory. Third World Quarterly, 23(4), 647-664.

Kay, C. (1989). Latin American Theories of Development and Underdevelopment. New York: Routledge.

Mander, J., \& Tauli-Corpuz, V. (Eds.). (2006). Paradigm Wars: Indigenous Peoples' Resistance to Globalization. San Francisco: Sierra Club Books.

Marini, R. M. (1972). Dialéctica de la Dependencia: La Economía Exportadora. Sociedad y Desarollo, no. 1.

Martinussen, J. (1997). Society, State \& Market: A Guide to Competing Theories of Development. Halifax, NS: Fernwood.

McLeod, J. (2000). Beginning Postcolonialism. Manchester University Press.

Meadows, D. H., Meadows, D. H., Randers, J., \& Behrens III, W. W. (1972). The Limits to Growth: A Report to the Club of Rome (1972). Google Scholar.

Myrdal, G. (1968). Asian Drama: An Inquiry into the Poverty of Nations. Harmondsworth: Penguin.

Nelson, N., \& Wright, S. (1995). Power and Participatory Development. London: Intermediate Technology.

Nurse, K. (2006). Culture as the Fourth Pillar of Sustainable Development. Small States: Economic Review and Basic Statistics, 11, 28-40.

Pieterse, J. N. (2000). After Post-Development. Third World Quarterly, 21(2), 174-191.

Polanyi, K. (1944/2001). The Great Transformation: The Political and Economic Origins of Our Time. Boston: Beacon Press. 
Prebisch, R. (1950). The Economic Development of Latin America and Its Principal Problems. New York: United Nations.

Quijano, A. (1977). Imperialismo y "Marginalidad" en Amérique Latina. Lima: Mosca Azul Editores.

Rahnema, M., \& Bawtree, V. (Eds.). (1997). The Post-Development Reader. London: Zed Books.

Rao, V., \& Walton, M. (2004). Culture and Public Action: Relationality, Equality of Agency, and Development. In V. Rao \& W. Walton (Eds.), Culture and Public Action (pp. 3-36). Stanford: Stanford University Press.

Sachs, W. (Ed.). (1991). The Development Dictionary: A Guide to Knowledge as Power. London: Zed Books.

Sahlins, M. (1976). Culture and Practical Reason. London: University of Chicago Press.

Said, E. (1979). Orientalism. New York: Vintage Books.

Salinas, R., \& Paldán, L. (1979). Culture in the Process of Dependent Development: Theoretical Perspectives. In K. Nordenstreng \& H. I. Schiller (Eds.), National Sovereignty and International Communication. New Jersey: Ablex.

Schiller, H. I. (1979). Transnational Media and National Development. In K. Nordenstreng \& H. I. Schiller (Eds.), National Sovereignty and International Communication. New Jersey: Ablex.

Senghor, L. S. (1956, June-November). The Spirit of Civilization or the Laws of African Negro Culture. Présence Africaine, 8-10.

Spivak, G. C. (1988). Can the Subaltern Speak? In C. Nelson \& L. Grossberg (Eds.), Marxism and the Interpretation of Culture. Urbana: University of Illinois Press.

Sunkel, O. (1969). National Development Policy and External Dependence in Latin America. Journal of Development Studies, 6(1), 23-48.

Tomlinson, J. (1991). Cultural Imperialism: A Critical Introduction. Baltimore: Johns Hopkins University Press.

Wallerstein, I. (1974). The Modern World System: Capitalist Agriculture and the Origins of the European World Economy in the Sixteenth Century. New York: Academic Press.

Wallerstein, I. (1979/2000). The Rise and Future Demise of the World Capitalist System: Concepts for Comparative Analysis. In J. Roberts \& A. Hite (Eds.), From Modernization to Globalization: Perspectives on Development and Social Change. Oxford: Blackwell.

Williams, R. (1977). Marxism and Literature. Oxford and New York: Oxford University Press. 
Open Access This chapter is licensed under the terms of the Creative Commons Attribution 4.0 International License (http://creativecommons.org/licenses/ by $/ 4.0 /$ ), which permits use, sharing, adaptation, distribution and reproduction in any medium or format, as long as you give appropriate credit to the original author(s) and the source, provide a link to the Creative Commons licence and indicate if changes were made.

The images or other third party material in this chapter are included in the chapter's Creative Commons licence, unless indicated otherwise in a credit line to the material. If material is not included in the chapter's Creative Commons licence and your intended use is not permitted by statutory regulation or exceeds the permitted use, you will need to obtain permission directly from the copyright holder. 